\title{
Pengaruh Pemberian Probiotik Isi Rumen dari Berbagai Ternak Ruminansia terhadap Penampilan Produksi Domba Batibul
}

\author{
Irwanto, Sunarso, dan Anis Muktiani \\ Fakultas Peternakan dan Pertanian, Universitas Diponegoro Corresponding \\ E-mail :irwanto116@gmail.com
}

\begin{abstract}
ABSTRAK
Penelitian ini bertujuan untuk mengkaji pengaruh pemberian probiotik isi rumen dari berbagai macam ternak ruminansia terhadap penampilan produksi domba dengan umur dibawah tiga bulan (Batibul). Materi yang digunakan adalah 15 ekor domba umur dibawah tiga bulan dengan bobot rata-rata sebesar 4,37 $\pm 0,27$ $\mathrm{kg}$. Penelitian dirancang melalui rancangan acak lengkap dengan 5 perlakuan dan 3 ulangan. Perlakuan tersebut meliputi $\mathrm{T} 0=$ konsentrat + hijauan; $\mathrm{T} 1=$ konsentrat + isi rumen sapi + hijauan; $\mathrm{T} 2=$ konsentrat + isi rumen kerbau + hijauan; T3 = konsentrat + isi rumen kambing + hijauan; dan T4 = konsentrat + isi rumen domba + hijauan. Pakan konsentrat dan hijauan diberikan secara ad libitum sedangkan isi rumen diberikan sebanyak 5\% dari pakan konsentrat. Berdasarkan hasil penelitian diketahui bahwa penambahan probiotik isi rumen dari berbagai ternak ruminansia tidak berpengaruh nyata terhadap penampilan produksi domba Batibul yang meliputi konsumsi bahan kering, pertambahan bobot badan harian, efisiensi dan konversi pakan.

Kata Kunci: Domba Batibul, Penampilan Produksi, Probiotik, Isi Rumen.
\end{abstract}

\begin{abstract}
This study aims to examine the effect of probiotic rumen contents from various kinds of ruminants on the performance of lamb under the age of three months (Batibul). The material used was 15 lambs aged under three months with an average body weight of $4.37 \pm 0.27 \mathrm{~kg}$. The study was arranged through a completely randomized design with 5 treatments and 3 replications. The treatment includes $T 0=$ concentrate + forage; $T 1=$ concentrate + rumen contents of cattle + forage $; T 2=$ concentrate + rumen contents of buffalo + forage; $T 3=$ concentrate + rumen contents of goat + forage $;$ and $T 4=$ concentrate + rumen contents of sheep + forage. Feed concentrates and forages are given ad libitum and the contents of the rumen are given $5 \%$ of the concentrate feed. Based on the results of the study it was found that the addition of probiotic rumen contents from various ruminants had no significant effect on the performance of Batibul lamb which included dry matter consumption, average daily gain, efficiency, and feed conversion.
\end{abstract}

Keywords: Batibul lamb, performance, Probiotic, Rumen Contents

\section{PENDAHULUAN}

Domba merupakan ternak ruminansia yang digemari oleh masyarakat terutama domba yang dipotong pada umur muda. Hal tersebut membuat pedagang sate mulai menjual daging domba yang dipotong pada umur tiga bulan (Budiarsana et al., 2016). Usaha penggemukan ternak domba harus didukung dengan pemberian pakan dengan kualitas yang baik. Pakan yang dikonsumsi oleh ternak akan dicerna dalam saluran pencernaan. Proses pencernaan ternak ruminansia sangat bergantung pada proses fermentasi oleh mikroba yang terdapat pada rumen. Proses fermentasi pakan berserat didalam rumen menghasilkan Volatile Fatty Acids (VFA) yang akan digunakan sebagai sumber energi pada ternak ruminansia (Haryanto, 2012). VFA merupakan hasil akhir dari proses fermentasi pada rumen. Semakin banyak mikrobia dalam rumen akan mempehrcepat pembentukan VFA.

Domba dengan umur dibawah tiga bulan (Batibul) memiliki jumlah populasi mikroba pada rumen masih sedikit sehingga belum optimal untuk mencerna pakan dengan serat kasar dalam jumlah banyak sehingga produksi VFA yang dihasilkan belum optimal, oleh karena itu perlu adanya 
penambahan probiotik untuk merangsang pertumbuhan mikrobia. Sehingga dapat meningkatkan asupan energi bagi ternak untuk berproduksi. Penggunaan probiotik bertujuan untuk membantu proses degradasi nutrien pakan dalam rumen (Haryanto et al., 2004).

Probiotik merupakan pakan tambahan berupa mikroorganisme yang dapat mencerna serat sebagai upaya peningkatan produktivitas ternak (Hau et al., 2005). Probiotik yang digunakan untuk merangsang perkembangan dan pertumbuhan mikroba pada rumen dapat berupa isi rumen dari ternak ruminansia kerbau, sapi, kambing atau domba dewasa yang telah dipotong pada Rumah Potong Hewan (RPH). Disisi lain pemanfaatan isi rumen sebagai sumber probiotik dapat mengurangi pencemaran limbah isi rumen yang dibuang oleh RPH selain itu pemberian isi rumen sebagai probiotik diharapkan dapat meningkatkan degradasi serat dan protein (Kuswandi et al., 2001). Peningkatan degradasi serat dan protein pada ternak diharapkan dapat meningkatkan konsumsi bakan kering, pertambahan bobot badan harian, efisiensi dan konversi pakan.

Penelitian ini bertujuan untuk mengkaji pengaruh pemberian probiotik isi rumen dari berbagai macam ternak ruminansia terhadap penampilan produksi yang meliputi konsumsi bakan kering, pertambahan bobot badan harian, efisiensi dan konversi pakan.domba dengan umur dibawah tiga bulan (Batibul).

\section{MATERI DAN METODE}

Penelitian dilaksanakan pada bulan Agustus-Desember 2017 di Kandang Digesti, Laboratorium Ilmu Nutrisi Pakan, Fakultas Peternakan dan Pertanian, Universitas Diponegoro, Semarang. Materi yang digunakan pada penelitian berupa 15 ekor Domba Ekor Tipis jantan dengan umur dibawah tiga bulan dengan bobot 4,37 $\pm 0,27 \mathrm{~kg}$. Bahan pakan yang digunakan yaitu konsentrat, hijauan dan probiotik isi rumen. Konsentrat yang digunakan pada penelitian ini berupa pakan starter yang terdiri atas dedak, pollard, bungkil kelapa, bungkil kedelai, tetes dan mineral mix. Hijauan yang digunakan berupa rumput gajah segar yang dicacah sebelum diberikan kepada ternak. Probiotik bersumber dari isi rumen ternak sapi, kerbau, kambing dan domba. Probiotik isi rumen diperoleh dari RPH Kota Semarang. Probiotik isi rumen disiapkan dengan mengeringkan isi rumen dibawah sinar matahari pada pukul 7 sampai , kemudian isi rumen yang telah kering di giling hingga halus menggunakan disc mill. Isi rumen yang telah halus kemudian dimasukan ke dalam kantong plastik dan ditutup rapat. Peralatan yang digunakan yaitu kandang panggung yang disekatsekat sebagai kandang individual, tempat pakan dan minum, ember, nampan, timbangan digital, timbangan analitik, botol timbang, oven dan eksikator.

\section{HASIL DAN PEMBAHASAN}

Tabel 1. Data Penampilan Produksi Domba Batibul

\begin{tabular}{|c|c|c|c|c|c|}
\hline \multirow{2}{*}{ Parameter Penelitian } & \multicolumn{5}{|c|}{ Perlakuan } \\
\hline & T0 & T1 & T2 & T3 & T4 \\
\hline $\begin{array}{ll}\begin{array}{l}\text { Konsumsi } \\
\text { (gram/hari) }\end{array} & \text { BK }\end{array}$ & 301,38 & 239,02 & 294,10 & 292,09 & 250,38 \\
\hline $\begin{array}{l}\text { Konsumsi BK terhadap } \\
\text { BB }(\%)\end{array}$ & 6,90 & 5,47 & 6,73 & 6,68 & 5,73 \\
\hline PBBH (gram/hari) & 66,69 & 50,67 & 69,44 & 66,34 & 49,05 \\
\hline Efisiensi (\%) & 22,06 & 20,11 & 22,64 & 21,94 & 18,69 \\
\hline Konversi & 4,64 & 4,60 & 4,06 & 4,60 & 5,47 \\
\hline
\end{tabular}

Keterangan: Nilai rataan Konsumsi BK, PBBH, Efisiensi dan Konversi menunjukkan pengaruh yang tidak berbeda nyata $(\mathrm{P}>0,5)$

\section{Konsumsi BK}

Berdasarkan analisis ragam Domba Batibul yang diberi probiotik isi rumen tidak berpengaruh nyata $(\mathrm{P}>0,05)$ terhadap konsumsi BK. Hal tersebut diduga karena pemberian probiotik isi rumen belum

mampu meningkatkan jumlah mikroba dalam rumen sehingga konsumsi BK pada ternak yang diberi pakan perlakuan memiliki konsumsi BK yang relatif sama dengan kontrol. Selain itu, pakan yang diberikan memiliki kualitas dan kandungan nutrien yang hampir sama. Tillman et al. (1998) menyatakan bahwa konsumsi pakan dipengaruhi oleh bentuk dan sifat fisik pakan, frekuensi pemberian pakan, komposisi kimia dan kandungan anti nutrisi pakan. Paramita et al. (2008) menyatakan bahwa palatabilitas pakan yang sama 
akan memberikan dampak konsumsi pakan yang sama pada ternak.

Rata-rata konsumsi BK ransum pada perlakuan T0, T1, T2, T3 dan T4 berturut - turut sebesar 301,38; 239,02; 294,10; 292,09 dan 250,38 dengan kemampuan konsumsi BK sebesar 6,90; 5,$47 ; 6,73 ; 6,68$ dan $5,73 \%$ dari bobot badan. Konsumsi BK pada penelitian ini lebih rendah dari penelitian yang dilakukan oleh Thalib et al. (2010) tentang penggunaan CRM (Complete Rumen Modifier) pada domba yang diberi pakan hijauan berserat tinggi sebesar 639, 759, dan 770 gram/ekor/hari pada perlakuan kontrol, CRM lerak giling dan CRM berbasis ekstrak lerak dengan etanol. Hal tersebut diduga disebabkan oleh palatabilitas pakan perlakuan ini lebih rendah sehingga yang kurang disukai oleh domba. Cita rasa pada pakan mempengaruhi tingat konsumsi pada ternak. Church dan Pond (1988) menyatakan bahwa konsumsi pakan dipengaruhi oleh tingkat palatabilitas yang dipengaruhi oleh cita rasa, bau, tekstur, penampilan dan bentuk pakan.

\section{Pertambahan Bobot Badan Harian}

Berdasarkan analisis ragam diketahui bahwa domba yang diberi perlakuan penambahan probiotik isi rumen tidak berpengaruh nyata

$(\mathrm{P}>0,05)$ terhadap pertambahan bobot badan harian. Hal tersebut diduga karena pakan perlakuan belum mampu meningkatkan jumlah mikroba dalam rumen secara signifikan sehingga diperkirakan ternak domba Batibul yang diberi perlakuan menghasilkan VFA yang tidak berbeda sehingga memiliki pertambahan bobot badan harian yang relatif sama dengan ternak kontrol. Hasil tersebut juga dipengaruhi oleh tingkat konsumsi bahan

kering yang relatif sama pada tiap perlakuan. Pertambahan bobot badan merupakan hasil dari pemanfaatan pakan oleh ternak yang sangat bergantung pada kualitas pakan ternak. NRC (2007) menyatakan bahwa pertambahan bobot badan dipengaruhi oleh beberapa faktor meliputi konsumsi protein, umur, jenis ternak, kondisi tubuh dan manajemen pemeliharaan. Ekawati et al. (2014) menyatakan bahwa konsumsi bahan kering pakan dengan kandungan nutrien yang sama akan menghasilkan pertambahan bobot badan harian yang sama pada ternak.

Pertambahan bobot badan harian pada perlakuan T0, T1, T2, T3 dan T4 sebesar 66,69; 50,67; 69,44; 66,$34 ; 49,05$. Hasil ini tidak jauh berbeda dari penelitian Jarmuji (2010) yang melakukan penelitian tentang pengaruh produksi susu induk terhadap pertambahan bobot badan anak Domba Ekor Tipis Jawa periode prasapih menghasilkan pertambahan bobot badan harian sebesar 43,00; 62,57 dan 77,06 gram/ekor/hari pada anak domba jantan dengan produksi susu induk kurang dari 300, 300-500 dan lebih dari 500 gram/ekor/hari. Menurut Haryanto et al. (2004) jumlah konsumsi pakan menentukan jumlah zat nutrien pakan yang diperoleh ternak yang selanjutnya digunakan untuk produktivitas.

\section{Efisiensi Pakan}

Berdasarkan data hasil penelitian diketahui bahwa pemberian probiotik isi rumen tidak berpengaruh nyata $(\mathrm{P}>0,05)$ terhadap efisiensi pakan domba Batibul. Hal tersebut dikarenakan pertambahan bobot badan harian dan konsumsi BK pakan yang relatif sama sehingga memiliki efisiensi pakan yang relatif sama. Efisiensi pakan merupakan persentase perbandingan antara pertambahan bobot badan dengan pakan yang dikonsumsi oleh ternak. Semakin tinggi nilai efisiensi pakan maka pemanfaatan pakan yang digunakan untuk pertambahan bobot badan semakin baik.

Rata-rata efisiensi pakan pada perlakuan T0, T1, T2, T3 dan T4 berturut - turut sebesar 22,06; 20,11; 22,64; 21,94; dan 18,69\%. Hasil penelitian ini lebih tinggi dibandingkan dengan Ekawati et al. (2014) tentang penggunaan silase ransum komplit eceng gondok ditambahkan starter Lactobacillus plantarum pada domba umur 12 bulan yang memiliki nilai efisiensi pakan sebesar $13,23 \%$ $14,09 \%$. Hal tersebut dikarenakan domba batibul memasuki fase pertumbuhan eksponensial sehingga efisiensi pakan yang lebih tinggi. Forbes (1995) menyatakan bahwa efisiensi pakan ditentukan oleh pertambahan bobot badan serta bahan pakan yang dikonsumsi oleh ternak. Menurut Tarmidi (2004) Efisiensi pakan dipengaruhi oleh kecernaan zat pakan, kualitas dan kuantitas pada pakan yang dikonsumsi oleh ternak.

\section{Konversi Pakan}

Penambahan probiotik isi rumen dari berbagai ternak ruminansia tidak berpengaruh nyata $(\mathrm{P}>0,05)$. Hal tersebut dikarenakan domba Batibul yang diberi probiotik isi rumen memiliki konsumsi bahan kering dan pertambahan bobot badan harian yang relatif sama. Purbowati et al.. (2009) menyatakan bahwa konversi pakan dipengaruhi tingkat konsumsi bahan kering pada ternak. Ratarata konversi pakan pada perlakuan T0, T1, T2, T3 dan T4 berturut - turut sebesar 4,64; 4,60; 4,06; 4,60 ; dan 5,47. Konversi pakan pada penelitian ini lebih baik dari Wazeer (2016) yang memiliki nilai konversi 6,74; 6,46; 6,71 dan 7,17 pada domba yang diberi isi rumen sapi dengan level $0 \%, 10 \%, 20 \%$ dan $30 \%$. Konversi pakan yang lebih rendah menunjukkan penggunaan pakan yang dibutuhkan untuk menaikkan bobot badan semakin sedikit. Konversi pakan digunakan untuk menilai efisiensi produksi pada ternak, semakin kecil nilai konversi maka efisiensi pakan semakin tinggi. Rianto et al. 
(2006) menyatakan bahwa konversi pakan merupakan perbandingan antara jumlah pakan yang dikonsumsi dengan pertambahan bobot badan ternak. Thalib et al. (2010) menyatakan bahwa nilai konversi pakan dipengaruhi oleh tingkat kecernaan pakan dan proses metabolisme yang berlangsung pada saluran pencernaan ternak.

\section{KESIMPULAN}

Kesimpulan yang diperoleh dari penelitian yaitu pemberian probiotik isi rumen dari berbagai macam ternak ruminansia tidak berpengaruh terhadap penampilan produksi domba dengan umur dibawah tiga bulan (Batibul).

\section{REFERENSI}

Budiarsana, I. G. M., B. Wibowo dan D. Priyanto. 2016. Produktivitas dan rantai pasok ternak kambing dan domba (KADO) studi kasus di kabupaten tegal. Jurnal Ilmu Ternak 16 (2) : 35 $-42$

Church, D. C. dan W. G. Pond. 1988. Basic Animal Nutrition and Feeding 3rd Ed. John Wiley \& Sons, New York.

Ekawati, E., A. Muktiani dan Sunarso. 2014. Efisiensi dan kecernaan pakan domba yang diberi silase pakan komplit Eceng Gondok ditambahkan starter Lactobacillusplantarum. J. Agripet. 14 (2) : 107 - 114.

Forbes. J. M. 1995. Voluntary Food Intake and Diet Selection in Farm Animal. CAB International, Wallingford.

Haryanto, B. 2012. Perkembangan penelitian nutrisi ruminansia. Wartazoa 22 (4) : 169 - 177.

Haryanto, B., Supriyati dan S. N. Jarmani. 2004. Pemanfaatan probiotik dalam bioproses untuk meningkatkan nilai nutrisi jerami padi untuk pakan domba. Prosiding Seminar Nasional Teknologi Peternakan dan Veteriner, Bogor. Hal: 298 - 304.

Hau, D. K., M. Nenobais, J. Nulik dan N. G. F. Katipana. 2005. Pengaruh probiotik terhadap kemampuan cerna mikroba rumen sapi Bali. Prosiding Seminar Nasional Teknologi Peternakan dan Veteriner, Bogor. Hal: 171 180.

Jarmuji, J. 2010. Produksi susu induk terhadap pengaruh pertambahan bobot badan, bobot sapih dan daya hidup anak domba ekor tipis jawa periode prasapih. Jurnal Sain Peternakan Indonesia, 5 (1) : 34 - 42.

Kuswandi, S., B. Haryanto, M. Martawidjaja dan D. Yulistiyani. 2001. Pertumbuhan domba muda yang diberi pakan aditif. Prosiding Seminar
Nasional Teknologi Peternakan dan Veteriner, Bogor. Hal: 181 - 188.

National Research Council. 2007. Nutrient Requirements of Small Ruminants: Sheep, Goats, Cervids, and New World Camelids. The National Academies Press, Washington DC.

Paramita, W., W. E. Susanto dan A. B. Yulianto. 2008. Konsumsi dan kecernaan bahan kering dan bahan organik dalam haylase pakan lengkap ternak sapi Peranakan Ongole. Media Kedokteran Hewan 24 (1) : 59 - 62.

Purbowati, E., C. I. Sutrisno, E. Baliarti, S. P. S. Budhi, W. Lestariana, E. Rianto, dan Kholidin. 2009. Penampilan produksi domba lokal jantan dengan pakan komplit dari berbagai limbah pertanian dan agroindustri. Prosiding Seminar Nasional Kebangkitan Peternakan, Semarang. Hal : $130-138$.

Rianto, E., D. Anggalina, S. Dartosukarno dan A. Purnomoadi. 2006. Pengaruh metode pemberian pakan terhadap produktivitas domba Ekor Tipis. Prosiding Seminar Nasional Teknologi Peternakan dan Veteriner 2006, Bogor. Hal: 361 - 364.

Steel, R. G. D. dan J. H. Torrie. 1995. Prinsip dan Prosedur Statistika Suatu Pendekatan Biometric. Gramedia Pustaka Utama, Jakarta.

Sutardi, T. 2001. Revitalisasi Peternakan Sapi Perah melalui Penggunaan Ransum Berbasis Limbah Perkebunan dan Suplemen Mineral Organik. Laporan Akhir RUT VIII. 1. Kantor Menteri Riset dan Teknologi dan Lembaga Ilmu Pengetahuan Indonesia, Jakarta.

Tarmidi, A. R. 2004. Pengaruh pemberian ransum yang mengandung ampas tebu hasil biokonversi oleh jamur tiram putih (Pleurotus ostreatus) terhadap performans domba Priangan. J. Ilmu Ternak dan Veteriner 9 (3) : $157-163$.

Thalib, A., Y. Widiawati dan B. Haryanto. 2010. Penggunaan complete rumen modifier (CRM) pada ternak domba yang diberi hijauan pakan berserat tinggi. J. Ilmu Ternak dan Veteriner 15 (2) : 97 - 104.

Tillman, A. D., H. Hartadi, S. Reksohadiprodjo, S. Prawirokusumo dan S. Lebdosukojo. 1998. Ilmu Makanan Ternak Dasar. Cetakan ke-4. Gadjah Mada University Press, Yogyakarta.

Wazeer, A. A. M. 2016. Effect of different levels of dried rumen content on nutrient intake, digestibility and growth performance of Awassi lambs. International Journal of Advanced Research. 4 (9): 2106 - 2113. 